\title{
Synthesis and Dynamic Random Access Memory Behavior of a Functional Polyimide
}

\author{
Qi-Dan Ling, ${ }^{\dagger}$ Feng-Chyuan Chang, ${ }^{\ddagger}$ Yan Song,${ }^{\S}$ Chun-Xiang Zhu, ${ }^{\S}$ \\ Der-Jang Liaw, ${ }^{\ddagger}$ Daniel Siu-Hhung Chan,${ }^{\S}$ En-Tang Kang, ${ }^{*},{ }^{\dagger}$ Koon- \\ Gee $\mathrm{Neoh}^{\dagger}$ \\ ${ }^{\dagger}$ Department of Chemical \& Biomolecular Engineering, National University of \\ Singapore, Kent Ridge, SINGAPORE, 119260 . Fax: 656779 1936; Tel: 656516 \\ 2189; E-mail: cheket@nus.edu.sg \\ ${ }^{\ddagger}$ Department of Chemical Engineering, National Taiwan University of Science and \\ Technology, Taipei, TAIWAN \\ $\S$ SNDL, Department of Electrical \& Computer Engineering, National University of \\ Singapore, Kent Ridge, SINGAPORE, 119260
}

${ }^{[*]}$ To whom all correspondence should be addressed.

Tel: +65-6516-2189; Fax: +65-6779-1936.

Email address: cheket@,nus.edu.sg 
Instrumentation. ${ }^{1} \mathrm{H}$ NMR and ${ }^{13} \mathrm{C}$ NMR spectra were measured on a Bruker Advanced 500 NMR spectrometer with $d_{6}$-dimethyl sulfoxide (DMSO) or $\mathrm{CDCl}_{3}$ as the solvents and tetramethylsilane as the internal standard. FT-IR spectra were recorded on a Bio-Rad Digilab FTS-3500 spectrometer. Elemental microanalysis (for $\mathrm{C}, \mathrm{H}$ and N) was performed on a Perkin-Elmer 2400 elemental analyzer. The inherent viscosity of polyimide was measured using Ubbelohde viscometer. Thermogravimetric analysis (TGA) was conducted on a TA instrument Dynamic TGA 2950 at a heating rate of $10^{\circ} \mathrm{C} / \mathrm{min}$ and under an air flow rate of $50 \mathrm{ml} / \mathrm{min}$. Differential scanning calorimetry (DSC) measurement was carried out on TA instrument LT-Modulate DSC 2920 under $\mathrm{N}_{2}$ and at a heating rate of $10^{\circ} \mathrm{C} / \mathrm{min}$. Weight-average $\left(M_{w}\right)$ and number-average molecular weights $\left(M_{n}\right)$ were determined by gel permeation chromatography (GPC). Four Waters Ultrastyragel ${ }^{\circledR}$ columns were used for GPC analysis, using tetrahydrofuran (THF; $1 \mathrm{~mL} / \mathrm{min}$ ) as the eluent. The eluents were monitored with a UV detector (JMST Systems, VUV-24, USA) at 254 $\mathrm{nm}$. Polystyrene samples were used as standards. XPS measurements were carried on Kratos AXIS HSi spectrometer with a monochromatized Al Ka X-ray source (1486.6 $\mathrm{eV}$ photons) at a constant dwell time of $100 \mathrm{~ms}$ and pass energy of $40 \mathrm{eV}$. The anode voltage and current were set at $15 \mathrm{kV}$ and $10 \mathrm{~mA}$, respectively. The pressure in the analysis chamber was maintained at $5 \times 10^{-8}$ Torr or lower during each measurement. Cyclic voltammetry $(\mathrm{CyV})$ measurements were performed on an Autolab potentiostat/galvanostat system using a three-electrode cell under an argon atmosphere. The polymer film on a Pt disk electrode (working electrode) with the active area of $7 \mathrm{~mm}^{2}$ and thickness of about $100 \mathrm{~nm}$ was scanned (scan rate: $0.1 \mathrm{~V} / \mathrm{s}$ ) anodically and cathodically in a solution of tetrabutylammonium hexafluorophosphate $\left(\mathrm{n}-\mathrm{Bu}_{4} \mathrm{NPF}_{6}\right)$ in acetonitrile $(0.1 \mathrm{M})$, with $\mathrm{Ag} / \mathrm{AgCl}$ and a platinum wire as the reference and counter electrode, respectively. The HOMO and LUMO energy levels of TP6F-PI can be calculated from the onset oxidation potential ( $\left.\mathrm{E}_{\mathrm{Ox}}(\mathrm{onset})\right)$ and the onset reduction potential ( $\left.\mathrm{E}_{\mathrm{Red}}(\mathrm{onset})\right)$, based on the reference energy level of ferrocene ( $4.8 \mathrm{eV}$ below the vacuum level, which is defined as zero): ${ }^{\mathrm{a}, \mathrm{b}}$

$$
\begin{aligned}
& \mathrm{HOMO}=-\left[\left(\mathrm{E}_{\mathrm{Ox}}(\text { onset })-\mathrm{E}_{\mathrm{Foc}}\right)+4.8\right](\mathrm{eV}) \\
& \mathrm{LUMO}=-\left[\left(\mathrm{E}_{\text {Red }}(\text { onset })-\mathrm{E}_{\mathrm{Foc}}\right)+4.8\right](\mathrm{eV}) \\
& \text { or } \\
& \mathrm{LUMO}=\mathrm{HOMO}-\mathrm{E}_{\mathrm{UV}} \text { edge } \\
& \text { (bandgap })(\mathrm{eV})
\end{aligned}
$$


wherein $\mathrm{E}_{\mathrm{Foc}}$ is the potential of external standard, ferrocene/ferricenium ion (Foc/Foc ${ }^{+}$) couple, E EV edge is the absorption edge of UV spectrum with the value in eV. The solution of ferrocene in toluene $(0.01 \mathrm{M})$ was used as the external standard.

(a) Bredas, J. L.; Silbey, R.; Boudreaux, D. S.; Chance, R. R. J. Am. Chem. Soc. 1983, $105,6555$.

(b) Lee, Y. Z.; Chen, X. W.; Chen, S. A.; Wei, P. K.; Fann, W. S. J. Am. Chem. Soc. 2001, 123, 2296.

Reagents for synthesis. $p$-Chloronitrobenzene was purchased from Wako Chemical Co. (Tokyo, Japan). Dimethyl sulfoxide (DMSO) was purchased from Tedia Co., Inc. (USA). Aniline, $10 \%$ palladium on activated carbon, potassium carbonate, hydrazine monohydrate, pyridine and acetic anhydride were purchased form Merck Chem. Co. (Anal. Grade) and were used as received. 4,4'-Hexafluoroisopropylidenediphathalic anhydride (from Lancaster, 99\%) was recrystallized from acetic anhydride and dried at $80^{\circ} \mathrm{C}$ under vacuum. $N$-Methyl-2-pyrrolidinone (NMP) and $N, N$-dimethylacetamide (DMAc) (from Merck Chem. Co.) was purified by distillation under reduced pressure over calcium hydride and stored over $4 \AA$ molecular sieves.

Synthesis of the 4,4'-dinitrotriphenylamine. A mixture of aniline ( $5 \mathrm{~g}, 54 \mathrm{mmol}), p$ chloronitrobenzene (19 g, $0.12 \mathrm{~mol})$, excess potassium carbonate (40 g, $0.29 \mathrm{~mol}$ ) and DMSO (40 mL) was refluxed at $150^{\circ} \mathrm{C}$ for $48 \mathrm{~h}$. After being cooled down to room temperature, the reaction mixture was poured into $1.2 \mathrm{~L}$ of cold water, the solid was isolated by filtration and dried at $100^{\circ} \mathrm{C}$. This crude product was further purified by recrystallization from ethanol. Yield: $41 \%$. M.P. $=184^{\circ} \mathrm{C} .{ }^{1} \mathrm{H}$ NMR $\left(d_{6}\right.$-DMSO, 500 $\mathrm{MHz}), \delta(\mathrm{ppm}): 8.17(4 \mathrm{H}, \mathrm{d}), 7.50(2 \mathrm{H}, \mathrm{t}), 7.35(1 \mathrm{H}, \mathrm{t}), 7.25(2 \mathrm{H}, \mathrm{d}), 7.19(4 \mathrm{H}, \mathrm{d}) .{ }^{13} \mathrm{C}$ NMR ( $d_{6}$-DMSO, $\left.125 \mathrm{MHz}\right), \delta(\mathrm{ppm}): 151.63,144.46,142.06,130.63,127.42,127.17$, 125.57, 122.42. FT-IR (solid, ATR cell, $\left.\mathrm{cm}^{-1}\right): 1326,1586\left(\mathrm{NO}_{2}\right)$.

4,4'-Diaminotriphenylamine monomer. A mixture of 4,4'-dinitrotriphenylamine $(0.86 \mathrm{~g}, 2.57 \mathrm{mmol}), 10 \% \mathrm{Pd} / \mathrm{C}(0.01 \mathrm{~g})$ and ethanol $(20 \mathrm{~mL})$ was placed in a twonecked flask, and heated to $80^{\circ} \mathrm{C}$. About $1.3 \mathrm{~mL}$ of hydrazine monohydrate was added dropwise over a period of $1 \mathrm{~h}$. After completion of the addition, the reaction mixture was refluxed for another $24 \mathrm{~h}$. The mixture was filtered to remove the $\mathrm{Pd} / \mathrm{C}$ catalyst. 
After cooling to room temperature, the precipitated crystals were isolated by filtration, recrystallized from ethanol and dried at $80^{\circ} \mathrm{C}$ under reduced pressure. Yield: $51 \%$. M.P. $=189^{\circ}$ C. Anal. calcd. for $\mathrm{C}_{18} \mathrm{H}_{17} \mathrm{~N}_{3}$ (wt\%): C, 78.52, H, 6.22, N, 15.26; Found: $\mathrm{C}$, 78.18, H, 6.21, N, 15.25. ${ }^{1} \mathrm{H}$ NMR (d ${ }_{6}$-DMSO, $\left.500 \mathrm{MHz}\right), \delta(\mathrm{ppm}): 7.05(2 \mathrm{H}, \mathrm{t}), 6.80$ $(4 \mathrm{H}, \mathrm{d}), 6.62(3 \mathrm{H}, \mathrm{q}), 6.54(4 \mathrm{H}, \mathrm{d}) .{ }^{13} \mathrm{C}$ NMR $\left(d_{6}\right.$-DMSO, $\left.125 \mathrm{MHz}\right), \delta(\mathrm{ppm}): 149.58$, $145.43,136.03,128.57,127.25,117.65,116.68,114.81$. FT-IR (KBr pellet, $\mathrm{cm}^{-1}$ ): $3424,3345\left(\mathrm{NH}_{2}\right)$.

Preparation of the polyimide (TP6F-PI). A flask was charged with 4,4'diaminotriphenylamine (TPDA, $0.10 \mathrm{~g}, 0.36 \mathrm{mmol}$ ), hexafluoroisopropyl bis(phthalic dianhydride) (6FDA, $0.16 \mathrm{~g}, 0.36 \mathrm{mmol}$ ) and $\mathrm{N}$-methyl-2-pyrrolidinone (NMP, $6 \mathrm{~mL}$ ). The mixture was stirred at room temperature for $12 \mathrm{~h}$ to form poly(amic acid). A mixture of acetic anhydride $(0.4 \mathrm{~mL})$ and pyridine $(0.4 \mathrm{~mL})$ was added to the poly(amic acid) solution. The resulting mixture was stirred at $110^{\circ} \mathrm{C}$ for $4 \mathrm{~h}$. After cooling to room temperature, the viscous polyimide solution was poured into methanol $(400 \mathrm{~mL})$, and the precipitate was collected by filtration. The crude polymer was washed thoroughly with methanol, re-dissolved into THF and re-precipitated from methanol twice. The final product was collected by filtration and dried at $180{ }^{\circ} \mathrm{C}$ under reduced pressure. The inherent viscosity of the polyimide in DMAc was 0.96 $\mathrm{dL} \mathrm{g}^{-1}$, measured at a concentration of $0.5 \mathrm{~g} \mathrm{dL}^{-1}$ at $30{ }^{\circ} \mathrm{C}$. The number average molecular weights $\left(M_{\mathrm{n}}\right)$ and weight average molecular weights $\left(M_{\mathrm{w}}\right)$ were $4.16 \times 10^{4}$ and $15.4 \times 10^{4}$, respectively, and the polydispersity index $\left(\mathrm{PDI}=M_{\mathrm{w}} / M_{\mathrm{n}}\right)$ was 3.70 , as determined from gel permeation chromatography (GPC) results. Anal. calcd. for $\mathrm{C}_{37} \mathrm{H}_{19} \mathrm{~F}_{6} \mathrm{O}_{4} \mathrm{~N}_{3}$ (wt\%): C, 65.01, H, 2.80, N, 6.15; Found: C, 64.42, H, 3.06, N, 6.17. ${ }^{1} \mathrm{H}$ NMR $\left(\mathrm{CDCl}_{3}, 500 \mathrm{MHz}\right.$, Figure S1), $\delta(\mathrm{ppm}): 8.04(\mathrm{~d}, 2 \mathrm{H}) ; 7.95$ (s, 2H); 7.87 (d, $2 \mathrm{H})$; 7.35-7.29 (m, 6H); 7.26-7.21 (m, 6H); $7.13(\mathrm{t}, 1 \mathrm{H}) .{ }^{13} \mathrm{C} \mathrm{NMR}\left(\mathrm{CDCl}_{3}, 125 \mathrm{MHz}\right.$, Figure S2), $\delta(\mathrm{ppm}): 147.34,146.70,139.07,135.85,132.67,132.38,129.65,127.37$, $125.79,125.45,125.25,124.39,124.03,123.81,64-66$. FT-IR (KBr pellet, $\left.\mathrm{cm}^{-1}\right)$ : 1784, 1724, 1378 and 723 (imide). XPS analysis results are shown in Figure S3. DSC and TGA results are shown in Figure S4 and S5, respectively. Figure S7 shows the UV-visible absorption spectrum of TP6F-PI in NMP. Figure S8 shows the cyclic voltammetry sweep of TP6F-PI. 


\section{Characterization data of TP6F-PI:}

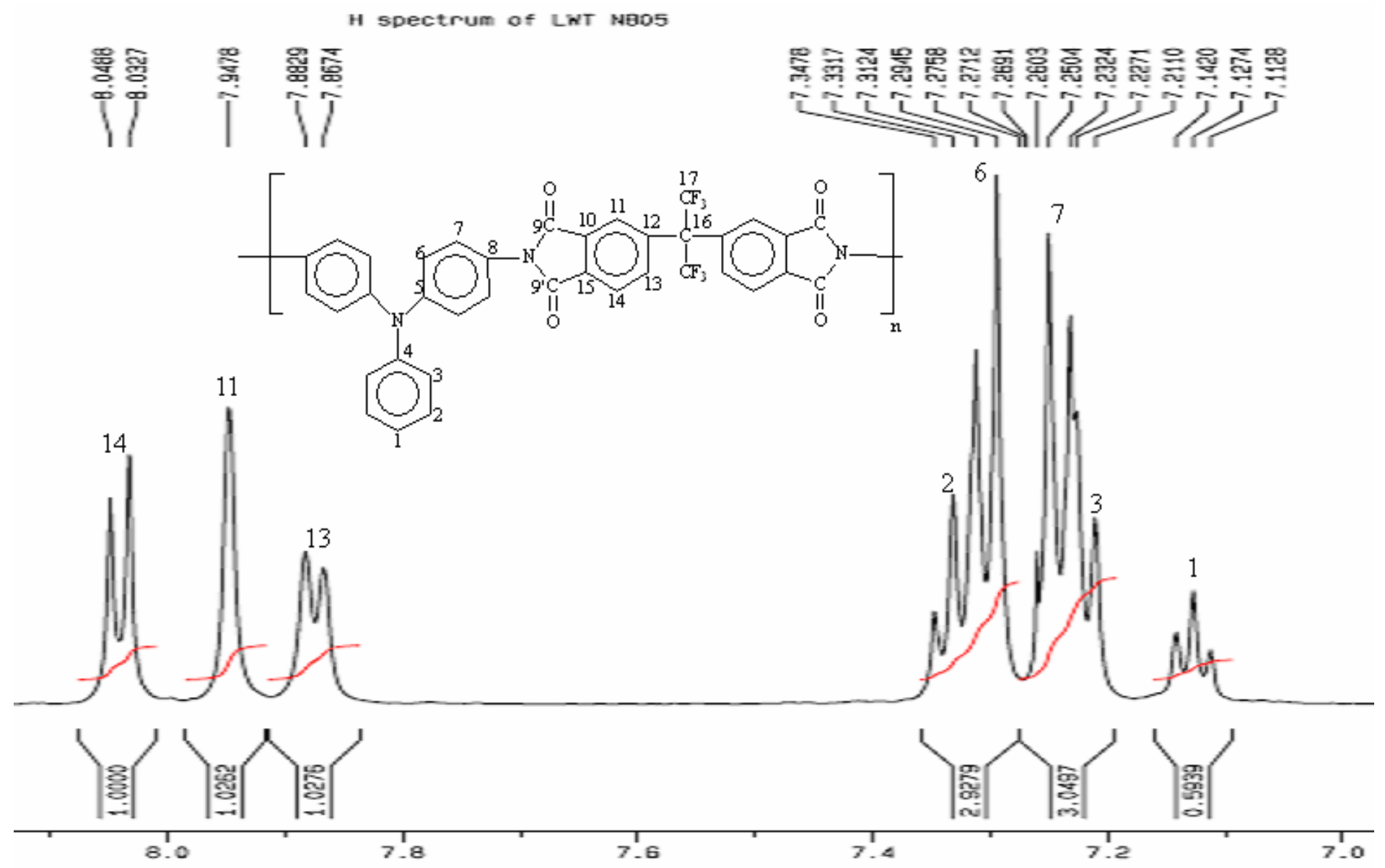

Figure S1. ${ }^{1} \mathrm{H}$ NMR (500 MHz) spectrum of TP6F-PI in $\mathrm{CDCl}_{3}$. 


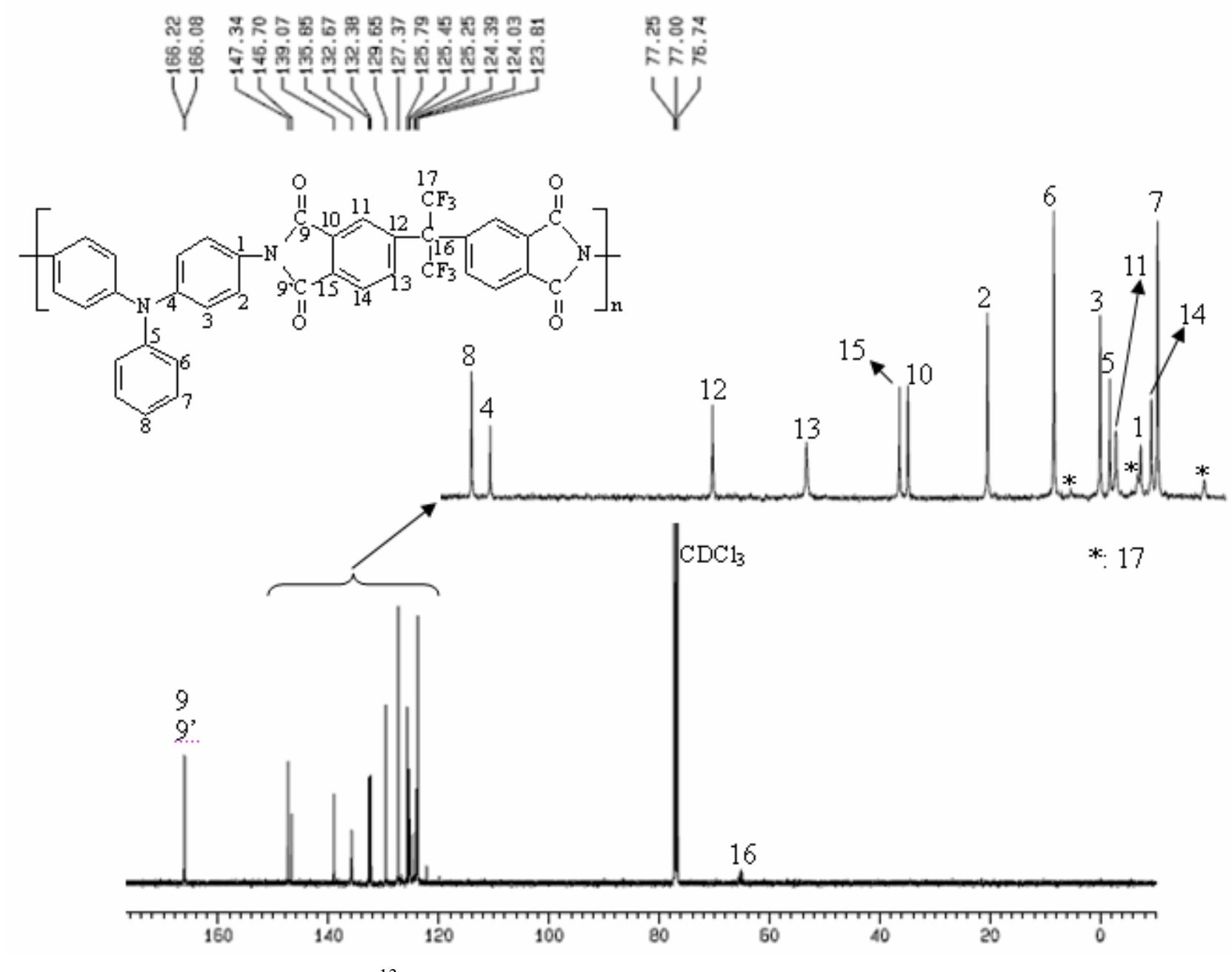

Figure S2. ${ }^{13} \mathrm{C}$ NMR (125 MHz) spectrum of TP6F-PI in $\mathrm{CDCl}_{3}$. 

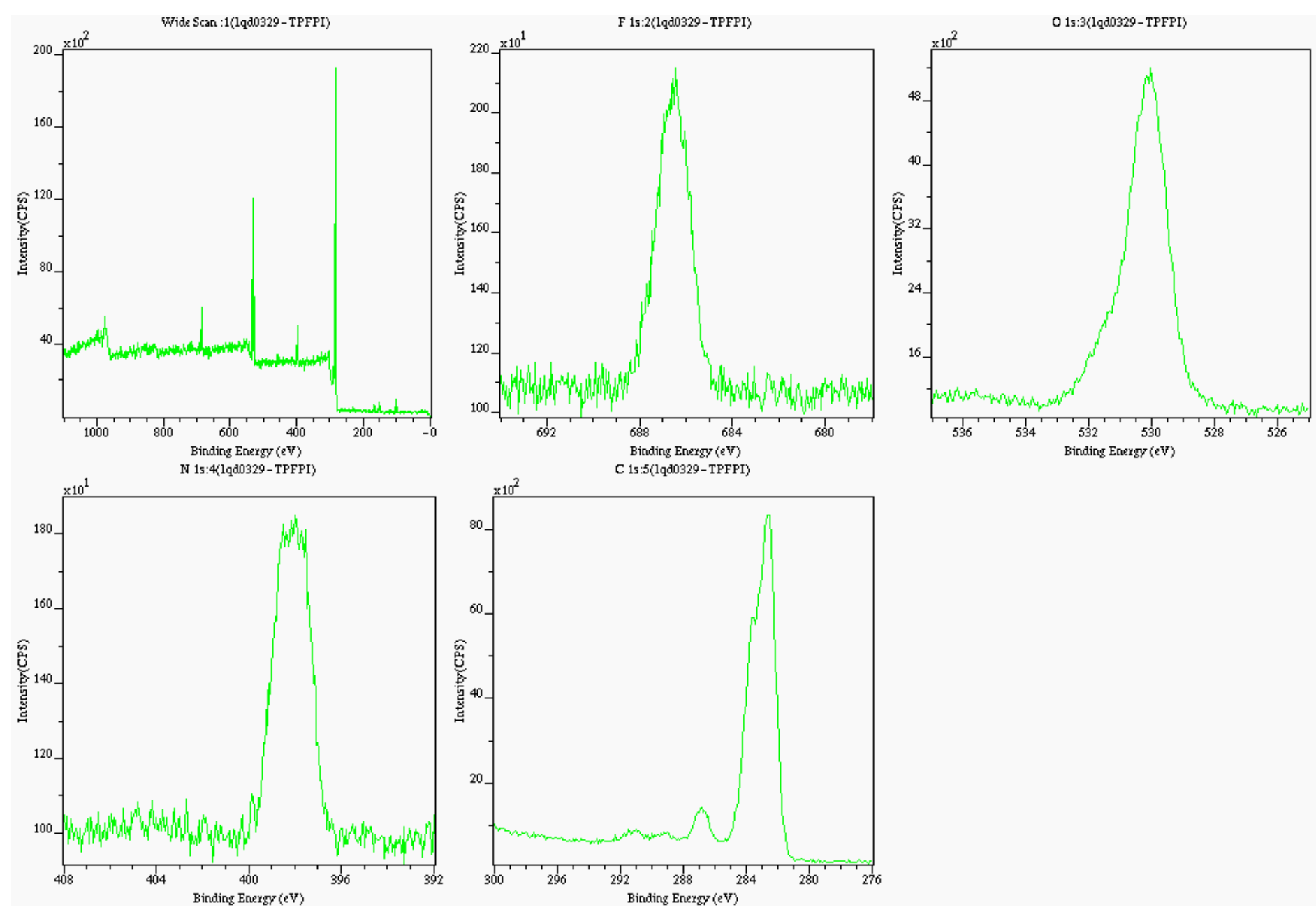

Figure S3. XPS survey scan, F 1s, O 1s, N 1s and C 1s core-level spectra of TP6F-PI. 


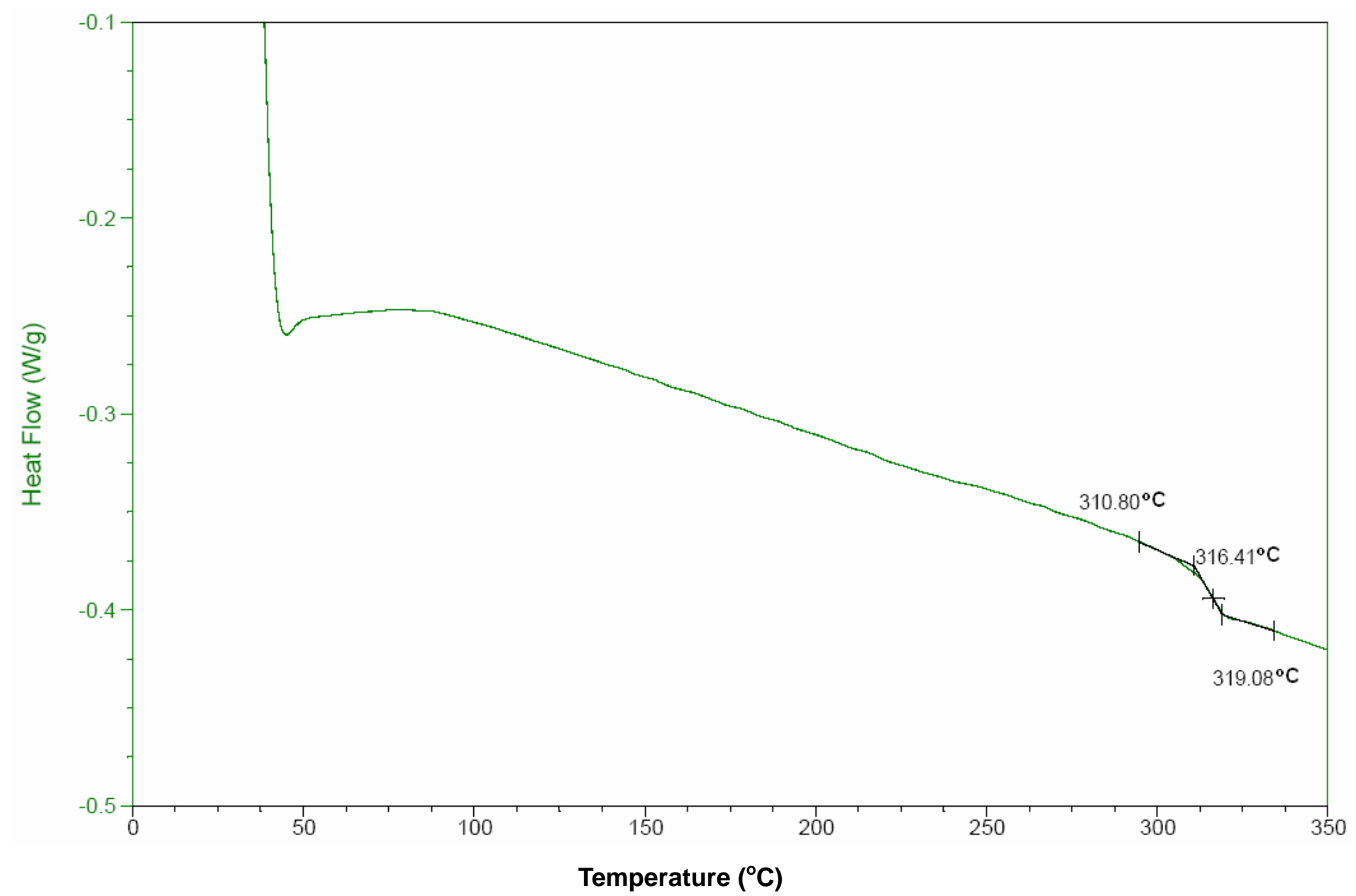

Figure S4. DSC scan of TP6F-PI measured in a nitrogen atmosphere (heating rate: $10^{\circ} \mathrm{C} / \mathrm{min}$ ). $\mathrm{T}_{\mathrm{g}}$ of TP6F-PI is about $316^{\circ} \mathrm{C}$. 


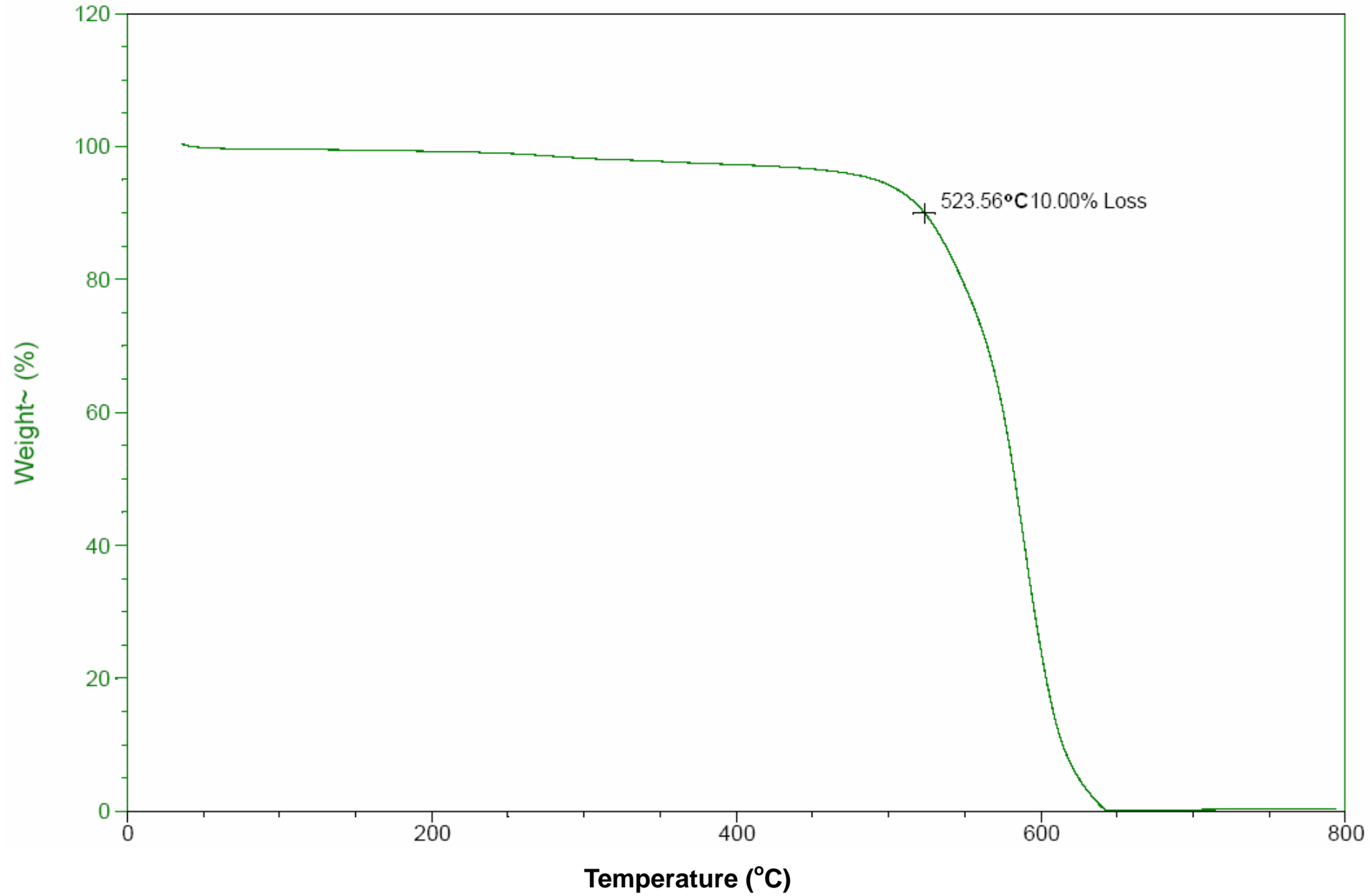

Figure S5. TGA curves of TP6F-PI measured in air at a heating rate of $10^{\circ} \mathrm{C} / \mathrm{min}$. 


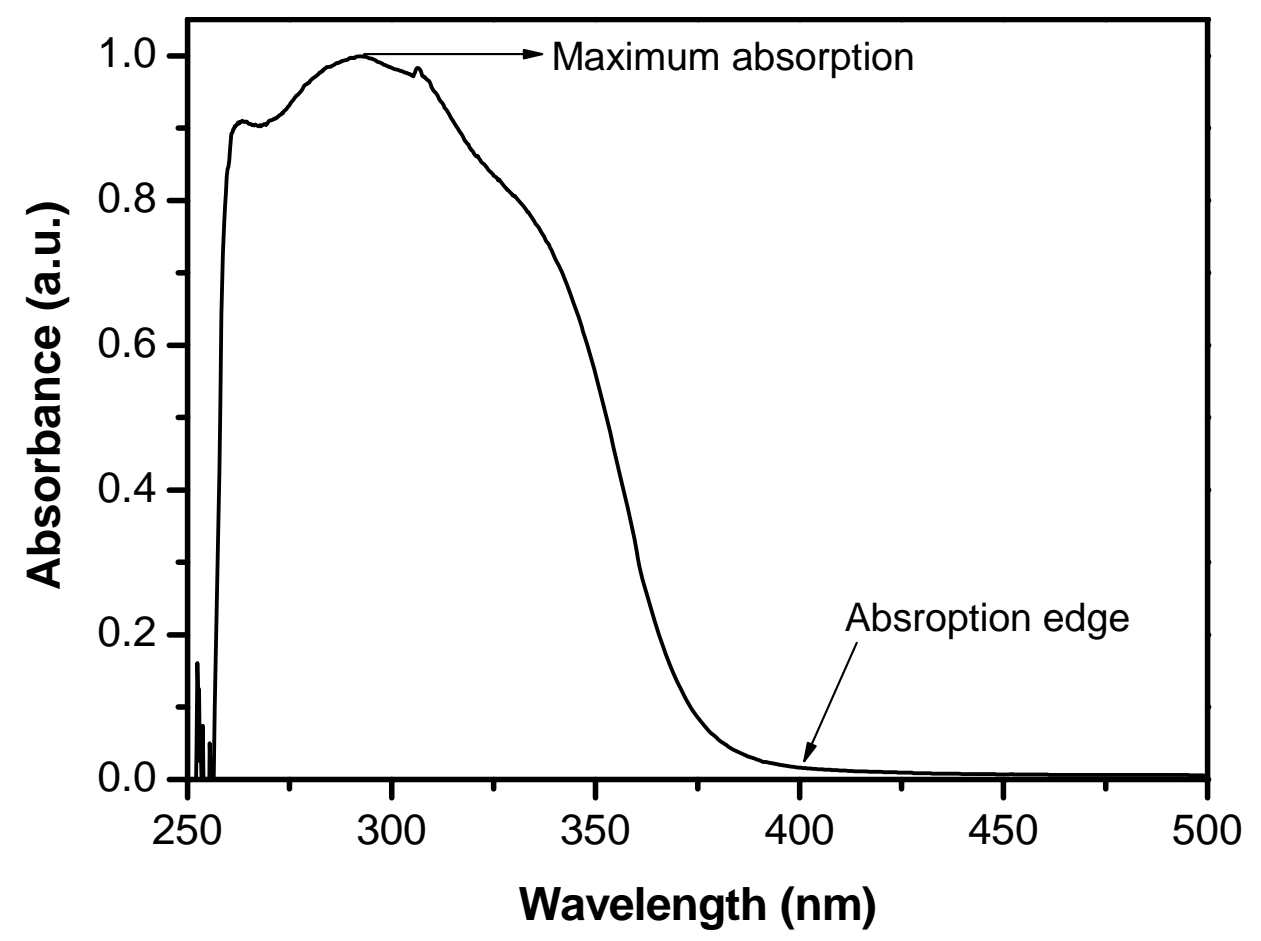

Figure S6. UV-visible absorption spectrum of TP6F-PI in dilute solution $\left(1.0 \times 10^{-5}\right.$ $\mathrm{mol} / \mathrm{L}$ of NMP).

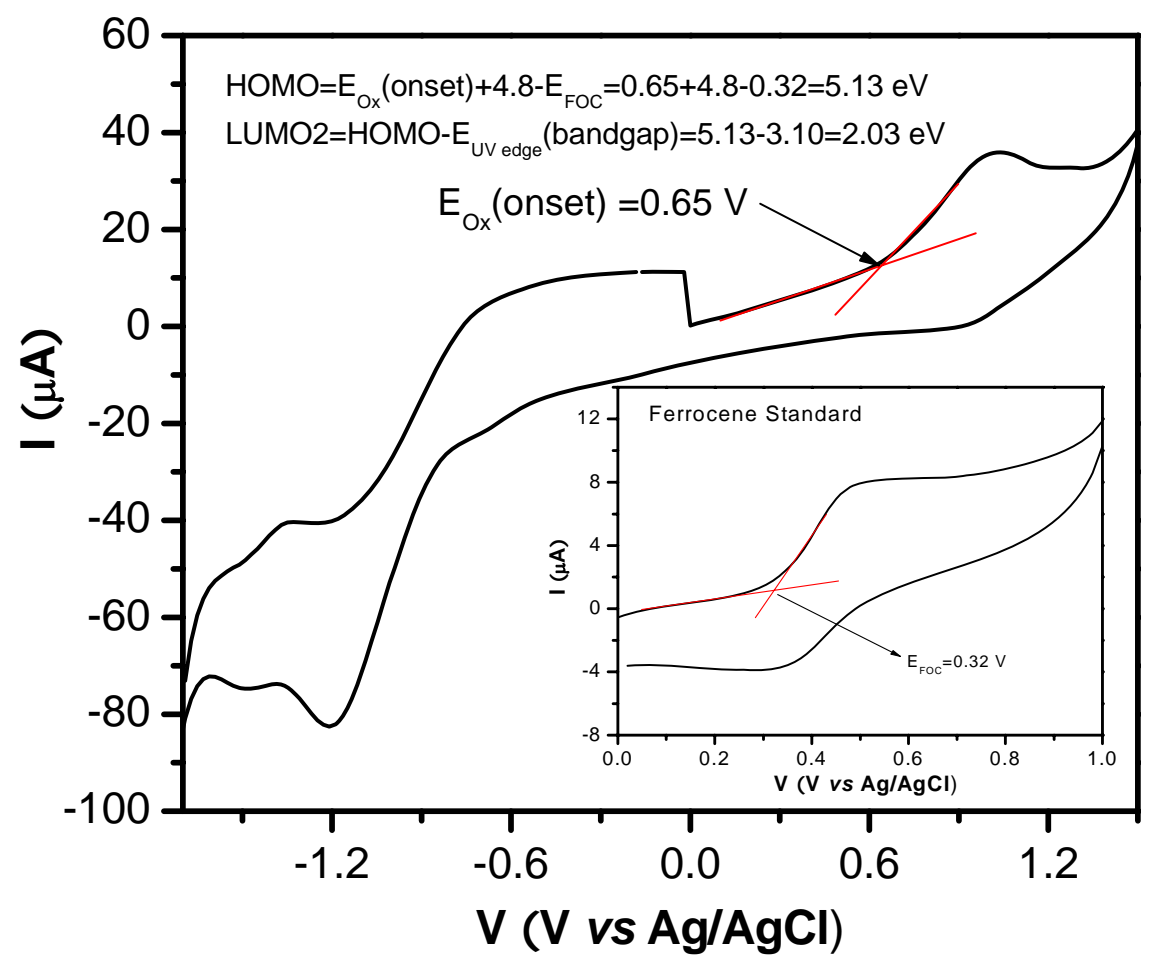

Figure S7. Cyclic voltammetry $(\mathrm{CyV})$ sweep (directions: (i) $0 \rightarrow 1.5 \mathrm{~V}$, (ii) $1.5 \rightarrow-1.7 \mathrm{~V}$, (iii) $-1.7 \rightarrow 0 \mathrm{~V}$ ) of TP6F-PI. The inset is the $\mathrm{CyV}$ of ferrocene standard, swept in the same conditions as that for TP6F-PI. 
Fabrication of the Memory Device. For the fabrication of the memory device, the indium-tin-oxide (ITO)/glass substrate was pre-cleaned with water, acetone and isopropanol, in that order, in an ultrasonic bath for $15 \mathrm{~min}$. A NMP solution of TP6FPI $(10 \mathrm{mg} / \mathrm{ml})$ was spin-coated onto ITO, followed by solvent removal in a vacuum chamber at $10^{-5}$ Torr and $100^{\circ} \mathrm{C}$ for $12 \mathrm{~h}$. The thickness of the polyimide layer was about $50 \mathrm{~nm}$. Aluminium top electrodes (for needle contacts) of $0.4 \times 0.4,0.2 \times 0.2$, $0.15 \times 0.15 \mathrm{~mm}^{2}$ and $0.3 \mu \mathrm{m}$ in thickness were thermally evaporated onto the polymer surface at about $10^{-7}$ Torr through a shadow mask. The devices were characterized, under ambient conditions, using a Hewlett-Packard 4156A semiconductor parameter analyzer equipped with an Agilent 16440A SMU/pulse generator.

Calculations of the molecular orbitals and electronic properties. Molecular simulations of the basic unit of TP6F-PI were carried out using the Gaussian 03 (Revision D 01) program package (Reference 15 below) on a HP XW6200 Workstation with 2 CPUs and 3 GB memory. The molecular orbitals and electronic properties were calculated by the density function theory (DFT), using the Becke's three parameter functional with the Lee, Yang, and Parr correlation functional method (B3LYP) and the basic set 6-31G with d function added to heavy atoms (in short, DFT B3LYP/6-31G(d)).

\section{Complete Reference 16 in the main text:}

(16) Frisch, M. J.; Trucks, G. W.; Schlegel, H. B.; Scuseria, G. E.; Robb, M. A.; Cheeseman, J. R.; Montgomery, J. A.; Vreven, Jr. T.; Kudin, K. N.; Burant, J. C.; Millam, J. M.; Iyengar, S. S.; Tomasi, J.; Barone, V.; Mennucci, B.; Cossi, M.; Scalmani, G.; Rega, N.; Petersson, G. A.; Nakatsuji, H.; Hada, M.; Ehara, M.; Toyota, K.; Fukuda, R.; Hasegawa, J.; Ishida, M.; Nakajima, T.; Honda, Y.; Kitao, O.; Nakai, H.; Klene, M.; Li, X.; Knox, J. E.; Hratchian, H. P.; Cross, J. B.; Bakken, V.; Adamo, C.; Jaramillo, J.; Gomperts, R.; Stratmann, R. E.; Yazyev, O.; Austin, A. J.; Cammi, R.; Pomelli, C.; Ochterski, J. W.; Ayala, P. Y.; Morokuma, K.; Voth, G. A.; Salvador, P.; Dannenberg, J. J.; Zakrzewski, V. G.; Dapprich, S.; Daniels, A. D.; Strain, M. C.; Farkas, O.; Malick, D. K.; Rabuck, A. D.; Raghavachari, K.; Foresman, J. B.; Ortiz, J. V.; Cui, Q.; Baboul, A. G.; Clifford, S.; Cioslowski, J.; Stefanov, B. B.; Liu, G.; Liashenko, A.; Piskorz, P.; Komaromi, I.; Martin, R. L.; Fox, D. J.; Keith, T.; Al-Laham, M. A.; Peng, C. Y.; 
Nanayakkara, A.; Challacombe, M.; Gill, P. M. W.; Johnson, B.; Chen, W.;

Wong, M. W.; Gonzalez, C.; Pople, J. A. Gaussian 03 (Revision D.01), Gaussian, Inc., Wallingford CT, 2004.

\section{Additional calculation results of the basic unit of TP6F-PI:}

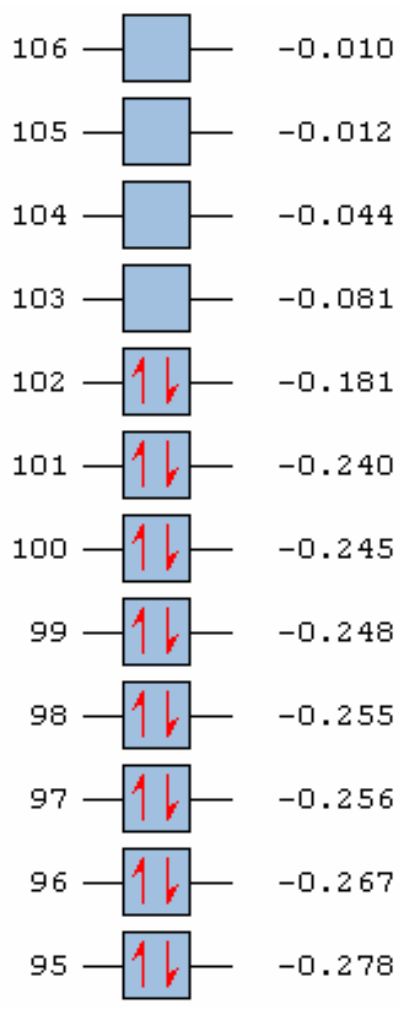

(Note: The unit of energy level is Hartree, 1 Hartree=27.2116 Electron volts $(\mathrm{eV})$ )

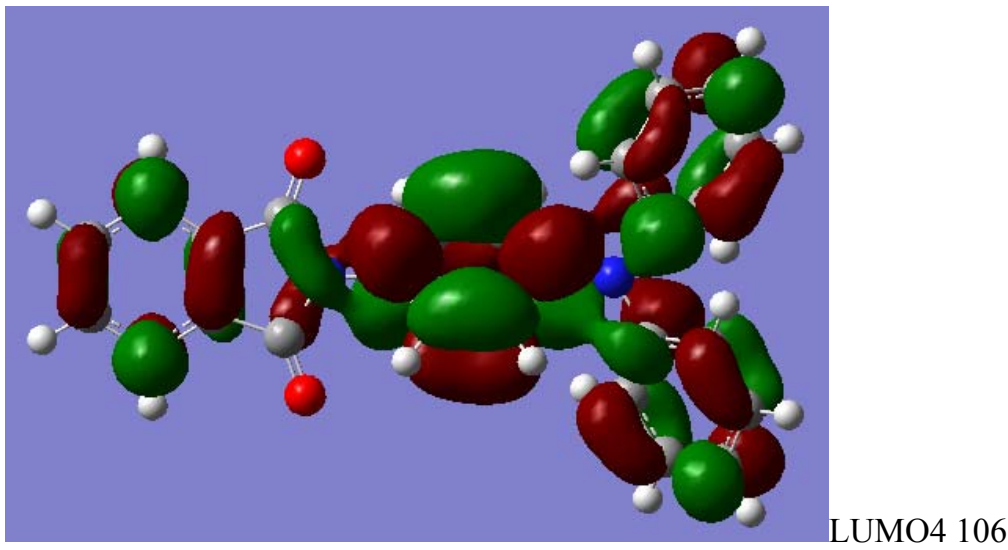



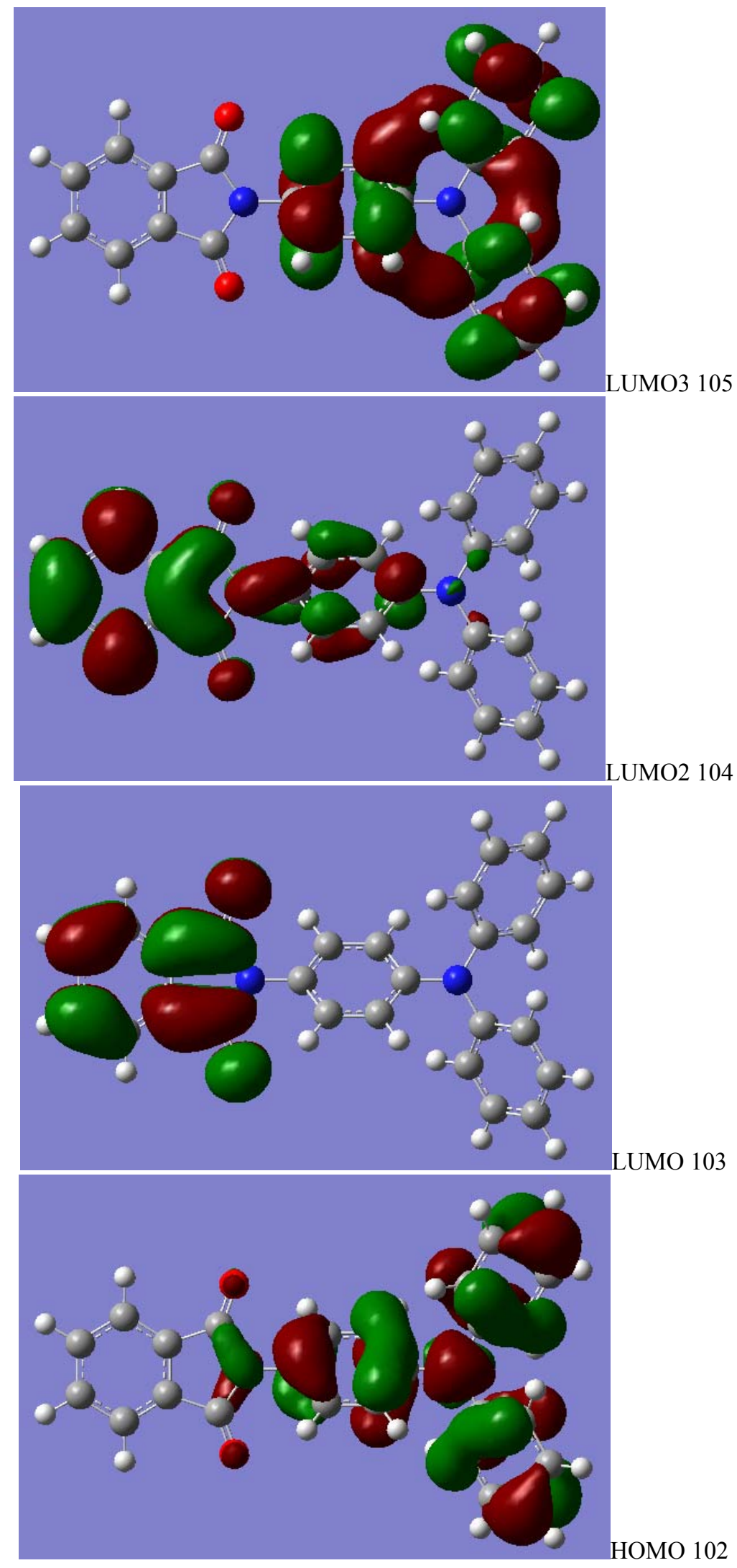

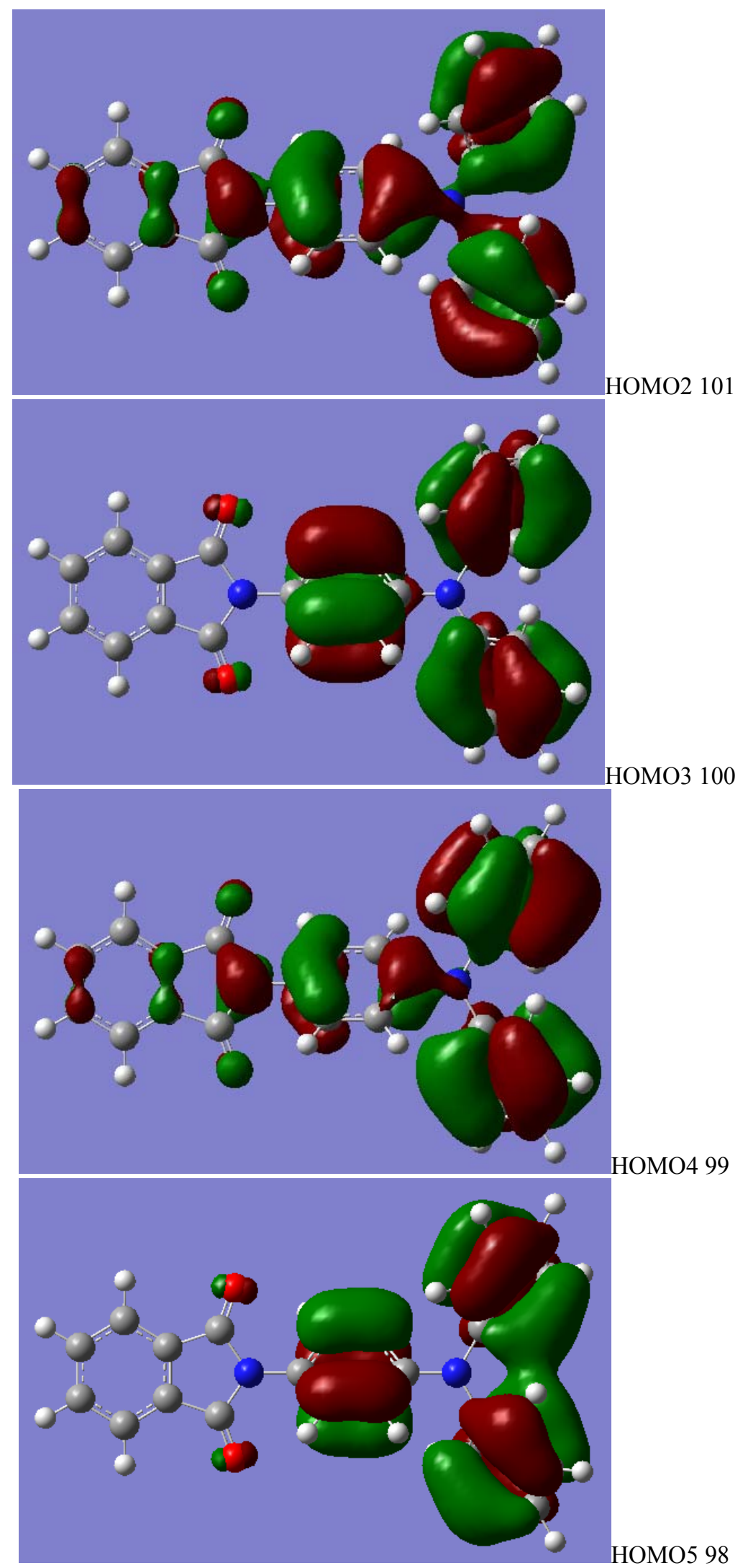

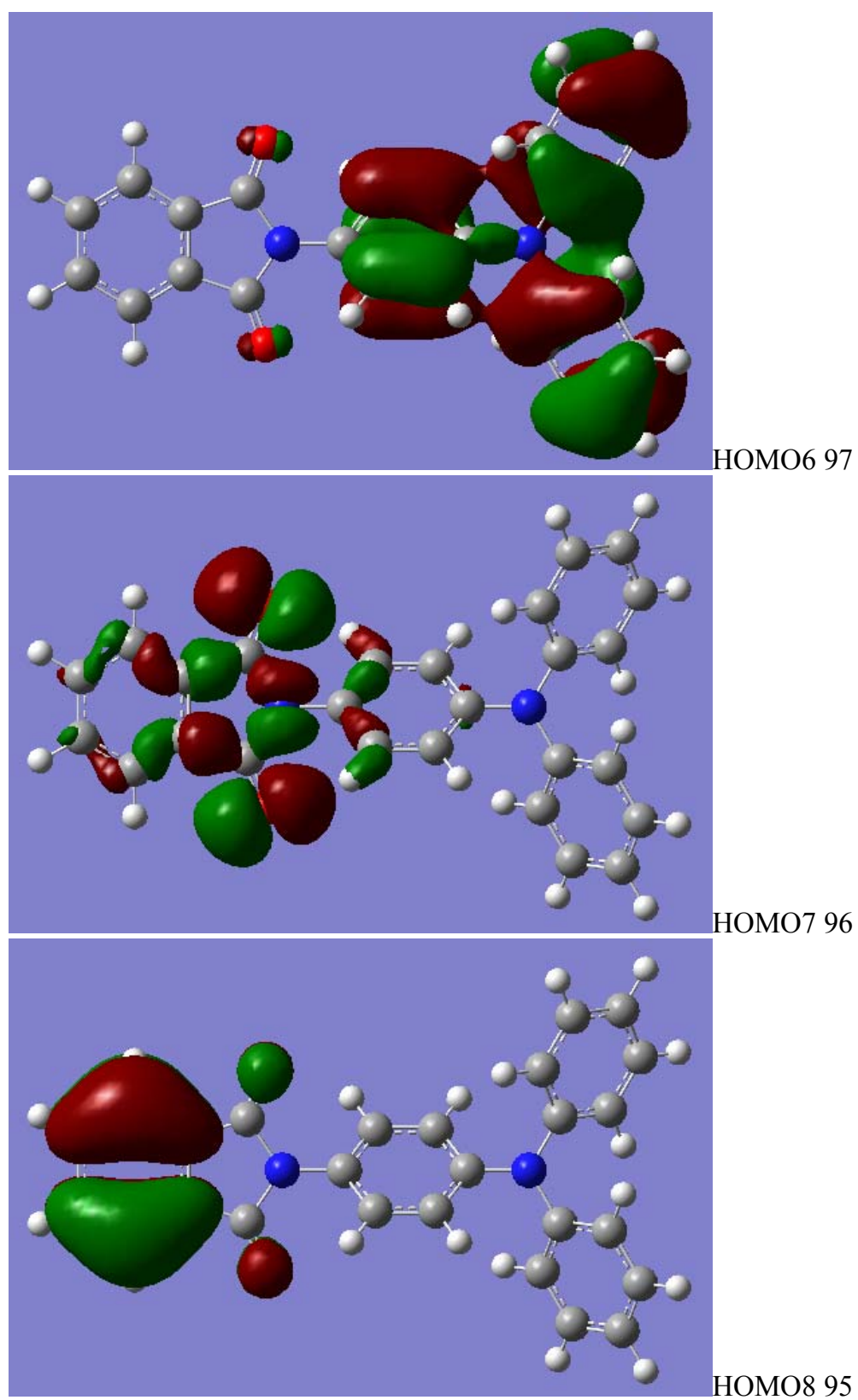